\title{
PENGARUH PERSEPSI SISWA ATAS FASILITAS DAN KOMPETENSI PEDAGOGIK GURU TERHADAP HASIL BELAJAR EKONOMI PADA SISWA SMAN 21 BEKASI
}

\author{
Elin Karlina ${ }^{1}$ dan Iswadi ${ }^{2}$ \\ ${ }^{1}$ Dosen Program Studi Pendidikan Ekonomi Universitas Indraprasta PGRI \\ ${ }^{2}$ Guru SMAN 21Bekasi \\ E-mail : elinkarlina27@yahoo.com
}

\begin{abstract}
Abstrak
Penelitian ini dilakukan di SMAN 21 Bekasi pada tahun ajaran 2017/2018 dengan tujuan untuk mengetahui 1). pengaruh yang signifikan secara bersama-sama persepsi siswa atas fasilitas dan kompetensi pedagogik guru terhadap hasil belajar Ekonomi pada siswa SMAN 21 Bekasi, 2). Pengaruh yang signifikan persepsi siswa atas fasilitas terhadap hasil belajar Ekonomi pada siswa SMAN 21 Bekasi, 3) Pengaruh yang signifikan kompetensi pedagogik guru terhadap hasil belajar Ekonomi pada siswa SMAN 21 Bekasi. Metode yang digunakan adalah kuantitatif dengan pendekatan survey. Sampel yang digunakan dalam penelitian ini siswa sebanyak 30 orang dengan menggunakan random sampling. Teknik analisis data yang digunakan adalah regresi berganda. Adapun hasil penelitian ini adalah 1). Tidak terdapat pengaruh yang signifikan secara bersama-sama persepsi siswa atas fasilitas dan kompetensi pedagogik guru terhadap hasil belajar Ekonomi pada siswa SMAN 21 Bekasi Tahun Pelajaran 2017/2018, 2). Tidak terdapat pengaruh yang signifikan persepsi siswa atas fasilitas terhadap hasil belajar Ekonomi pada siswa SMAN 21 Bekasi Tahun Pelajaran 2017/2018, 3). Tidak terdapat pengaruh yang signifikan kompetensi pedagogik guru terhadap hasil belajar Ekonomi pada siswa SMAN 21 Bekasi Tahun Pelajaran 2017/2018.
\end{abstract}

Kata kunci : persepsi siswa, fasilitas, kompetensi pedagogik, hasil belajar ekonomi.

\section{PENDAHULUAN}

Pendidikan merupakan faktor yang mempengaruhi kemajuan suatu bangsa. Pendidikan yang berkualitas adalah pendidikan yang dapat meningkatkan kemampuan generasi mudanya untuk memiliki kemampuan yang berkualitas. Pendidikan di Indonesia masih banyak mengalami masalah dari permasalahan fasilitas belajar, sarana dan prasarana, dan kompetensi guru. Permasalahan ini membuat prestasi belajar siswa mengalami penurunan sehingga kualitas lulusan siswa masih belum sesuai dengan harapan guru dan orang tua.

Masih banyak SMAN yang belum memiliki fasilitas dan guru yang kompeten menjadi masalah utama yang melatarbelakangi menurunya hasil belajar, khususnya hasil belajar Ekonomi. SMAN 21 Bekasi merupakan Sekolah baru yang didirikan pada tahun 2016 yang awalnya belajarnya di SMAN 5 Bekasi dan kemudian pindah ke SDN 3 Jatimakmur pada tahun 2017. Oleh karena itu, fasilitas dan sarana dan prasarana yang 
ada belum memenuhi 8 standar pendidikan nasional yang diatur oleh Pemerintah. SMAN 21 Bekasi belum memiliki gedung sendiri, laboratorium komputer dan bahasa, dan sarana dan prasarana lainnya.

Permasalahan lainnya adalah para guru yang mengajar di SMAN 21 Bekasi masih belum memiliki pengalaman yang mumpuni karena mereka masih muda-muda dan belum memiliki sertifikasi sebagai guru. Oleh karena itu, masalah tersebut menjadi permasalahan yang harus segera diselesaikan oleh Kepala Sekolah SMAN 21 Bekasi.

Mata pelajaran Ekonomi memerlukan fasilitas dan kompetensi guru yang baik sehingga SMAN 21 Bekasi harus segera melengkapi fasilitas yang dibutuhkan oleh guru mata pelajaran Ekonomi, seperti perpustakaan, laboratorium komputer, laboratorium akuntansi, dan lain-lain. Di samping itu, SMAN 21 Bekasi harus memberikan pelatihanpelatihan kepada guru mata pelajaran Ekonomi agar memiliki kompetensi pedagogik yang baik.

Berdasarkan masalah-masalah tersebut, penelit mengadakan penelitian dengan judul, Analisis pengaruh persepsi siswa atas fasilitas dan kompetensi pedagogik guru terhadap hasil belajar Ekonomi pada siswa SMAN 21 Bekasi Tahun Pelajaran $2017 / 2018$.

\section{TINJAUAN PUSTAKA}

\section{Pengertian Hasil Belajar Ekonomi}

\section{Hasil Belajar}

Hasil belajar merupakan bagian terpenting dalam pembelajaran. Nana Sudjana (2009:3) mendefinisikan hasil belajar siswa pada hakikatnya adalah perubahan tingkah laku sebagai hasil belajar dalam pengertian yang lebih luas mencakup bidang kognitif, afektif, dan psikomotorik. Dimyati dan Mudjiono (2006: 3-4) juga menyebutkan hasil belajar merupakan hasil dari suatu interaksi tindak belajar dan tindak mengajar. Dari sisi guru, tindak mengajar diakhiri dengan proses evaluasi hasil belajar. Dari sisi siswa, hasil belajar merupakan berakhirnya pengajaran dari puncak proses belajar.

Benjamin S. Bloom (Dimyati dan Mudjiono, 2006: 26-27) menyebutkan enam jenis perilaku ranah kognitif, sebagai berikut: a. Pengetahuan, mencapai kemampuan ingatan tentang hal yang telah dipelajari dan tersimpan dalam ingatan. Pengetahuan itu berkenaan dengan fakta, peristiwa, pengertian kaidah, teori, prinsip, atau metode. $b$. 
Pemahaman, mencakup kemampuan menangkap arti dan makna tentang hal yang dipelajari. c. Penerapan, mencakup kemampuan menerapkan metode dan kaidah untuk menghadapi masalah yang nyata dan baru. Misalnya, menggunakan prinsip. d. Analisis, mencakup kemampuan merinci suatu kesatuan ke dalam bagian-bagian sehingga struktur keseluruhan dapat dipahami dengan baik. Misalnya mengurangi masalah menjadi bagian yang telah kecil. e. Sintesis, mencakup kemampuan membentuk suatu pola baru. Misalnya kemampuan menyusun suatu program. f. Evaluasi, mencakup kemampuan membentuk pendapat tentang beberapa hal berdasarkan kriteria tertentu. misalnya, kemampuan menilai hasil ulangan.

Berdasarkan kutipan-kutipan tersebut, dapat disimpulkan hasil belajar adalah perubahan tingkah laku yang mencakup kognitif, afektif, dan psikomotorik yang dihasilkan dari interaksi siswa dengan sumber belajar dan evaluasi yang dilaksanakan oleh guru.

\section{Ekonomi}

Menurut Sigit Winarno, dan Sujana Ismaya (2007:177), dalam kamus besar Ekonomi, economics diartikan sebagai ilmu ekonomi merupakan yang mempelajari asas-asas produksi, distribusi dan pemakaian barang-barang serta kekayaan, seperti keuangan, perindustrian, dan perdagangan; ilmu yang mempelajari usaha-usaha manusia untuk memenuhi kebutuhannya. Menurut Dasim Budimansyah (2003:1) "Ilmu ekonomi merupakan ilmu atau seni tentang upaya manusia untuk memenuhi kebutuhan hidupnya yang banyak, bervariasi dan berkembang dengan sumber daya yang ada melalui pilihan kegiatan produksi, konsumsi, dan distribusi”.

Peneliti menyimpulkan bahwa ekonomi yaitu ilmu yang mempelajari tentang upaya manusia untuk memenuhi kebutuhan hidupnya dengan cara memproduksi, mengkonsumsi, dan mendistribusikan dan mempelajari tentang sumber daya manusia dan bagaimana mengembangkan sumber daya manusia agar dapat memenuhi kebutuhan ekonominya.

\section{Hasil Belajar Ekonomi}

Hasil belajar Ekonomi adalah pengetahuan yang didapat oleh siswa setelah belajar mata pelajaran Ekonomi dengan guru mata pelajaran Ekonomi dengan cara melaksanakan tes materi mata pelajaran Ekonomi. 


\section{Pengertian Persepsi Siswa Atas Fasilitas dan Kompetensi Pedagogik Persepsi}

Persepsi menurut Kamus Bahasa Indonesia, persepsi berarti tanggapan (penerimaan) langsung hal melalui pancainderanya (Depdiknas, 2002:1239). Secara terminologi, terdapat beberapa rumusan tentang persepsi, diantaranya menurut Walgito, persepsi adalah mengelompokkan benda-benda yang berdekatan atau serupa, dapat memfokuskan perhatiannya pada satu objek, sedangkan objek-objek lain disekitarnya dianggap sebagai latar belakang. Kemampuan untuk membedakan, mengelompokkan, memfokuskan dan sebagainya itu, yang selanjutnya dinterpretasi (Walgito ,2004:86).

Selanjutnya menurut Sugihartono, dkk (2007: 8) mengemukakan bahwa persepsi adalah kemampuan otak dalam menerjemahkan stimulus atau proses untuk menerjemahkan stimulus yang masuk ke dalam alat indera manusia. Persepsi manusia terdapat perbedaan sudut pandang dalam penginderaan. Ada yang mempersepsikan sesuatu itu baik atau persepsi yang positif maupun persepsi negatif yang akan mempengaruhi tindakan manusia yang tampak atau nyata. Bimo Walgito (2004: 70) mengungkapkan bahwa persepsi merupakan suatu proses pengorganisasian, penginterpretasian terhadap stimulus yang diterima oleh organisme atau individu sehingga menjadi sesuatu yang berarti, dan merupakan aktivitas yang integrated dalam diri individu. Respon sebagai akibat dari persepsi dapat diambil oleh individu dengan berbagai macam bentuk. Stimulus mana yang akan mendapatkan respon dari individu tergantung pada perhatian individu yang bersangkutan.

Peneliti menyimpulkan bahwa persepsi adalah suatu proses pengoragnisasian informasi yang melibatkan pengetahuan seseorang untuk memandang objek yang dipersepsikan dengan kemampuan mempersepsikannya sehingga menjadi penilaian yang negatif maupun positif.

\section{Fasilitas}

Fasilitas merupakan segala hal yang dapat memudahkan dan melancarkan pelaksanaan kegiatan, yang dapat memudahkan kegiatan dapat berupa sarana dan prasarana. Kamus Besar Bahasa Indonesia (2008:389), “fasilitas adalah sarana melancarkan pelaksanaan fungsi. 
Arikunto, dan Lia Yuliana (2008:274), Fasilitas pembelajaran adalah semua yang diperlukan dalam proses belajar mengajar baik yang bergerak maupun yang tidak bergerak agar pencapaian tujuan pendidikan dapat berjalan dengan lancar, teratur, efektif dan efisien. Menurut E. Mulyasa (2004:49), menjelaskan bahwa fasilitas pembelajaran adalah peralatan dan perlengkapan yang secara langsung dipergunakan dan menunjang proses pendidikan, khususnya dalam proses belajar mengajar, seperti gedung, ruang kelas, buku, perpustakaan, laboraturium, meja, kursi, serta alat-alat dan media pengajaran lainnya

Menurut Suryosubroto (2004:114), fasilitas pembelajaran di bedakan menjadi 3 macam yaitu: alat pelajaran, alat peraga, media pengajaran. 1) Alat pelajaran. Alat pelajaran adalah semua benda yang dapat digunakan scara langsung oleh guru maupun siswa dalam proses belajar mengajar. Seperti buku tulis, buku paket, buku penunjang (LKS), papan tulis, penggaris papan tulis, spidol, penghapus papan tulis, meja dan kursi belajar, dan alat-alat praktek. 2) Alat peraga. Alat peraga adalah semua alat pembantu pendidikan dan pengajaran, dapat berupa benda ataupun perbuatan dari yang paling kongkrit sampai ke yang paling abstrak yang dapat mempermudah pemberian pengertian kepada siswa. Seperti atlas, globe, patung peraga, materi RPP, silabus, peta topografi dunia, peta topografi pulau, kerangka model pembelajaran, dan pengukur panjang kurva. Dengan pengertian ini, maka alat pelajaran dapat termasuk dalam lingkup alat peraga. 3) Media pembelajaran. Media adalah sarana pendidikan yang digunakan sebagai perantara dalam proses belajar mengajar untuk mempertinggi efektivitas dan efisiensi pendidikan.

Peneliti menyimpulkan fasilitas adalah alat yang dapat mempermudah proses belajar-mengajar yang berupa sarana dan prasarana seperti alat pelajaran, alat peraga, media pengajaran.

\section{Kompetensi Pedagogik}

Suparno (2005:24) menyatakan bahwa competency refers to an individual's knowledge, skill, ability or personality characteristics that directly influence job performance. Artinya, kompetensi mengandung aspek-aspek pengetahuan, ketrampilan (keahlian) dan kemampuan ataupun karakteristik kepribadian yang mempengaruhi kinerja. 
Secara lebih rinci, Spencer dan Spencer dalam Palan (2007:84) mengemukakan bahwa kompetensi menunjukkan karakteristik yang mendasari perilaku yang menggambarkan motif, karakteristik pribadi (ciri khas), konsep diri, nilai-nilai, pengetahuan atau keahlian yang dibawa seseorang yang berkinerja unggul (superior performer) di tempat kerja. Ada 5 (lima) karakteristik yang membentuk kompetensi yakni 1). Faktor pengetahuan meliputi masalah teknis, administratif, proses kemanusiaan, dan sistem. 2). Keterampilan; merujuk pada kemampuan seseorang untuk melakukan suatu kegiatan. 3). Konsep diri dan nilai-nilai; merujuk pada sikap, nilainilai dan citra diri seseorang, seperti kepercayaan seseorang bahwa dia bisa berhasil dalam suatu situasi. 4). Karakteristik pribadi; merujuk pada karakteristik fisik dan konsistensi tanggapan terhadap situasi atau informasi, seperti pengendalian diri dan kemampuan untuk tetap tenang dibawah tekanan. 5). Motif; merupakan emosi, hasrat, kebutuhan psikologis atau dorongan-dorongan lain yang memicu tindakan. Menurut Keputusan Kepala Badan Kepegawaian Negeri Nomor: 46A tahun 2003, tentang pengertian kompetensi adalah :kemampuan dan karakteristik yang dimiliki oleh seorang Pegawai Negeri Sipil berupa pengetahuan, keterampilan, dan sikap perilaku yang diperlukan dalam pelaksanaan tugas jabatannya, sehingga Pegawai Negeri Sipil tersebut dapat melaksanakan tugasnya secara profesional, efektif dan efisien. Selanjutnya, Wibowo (2007:86), kompetensi diartikan sebagai kemampuan untuk melaksanakan atau melakukan suatu pekerjaan atau tugas yang dilandasi oleh keterampilan dan pengetahuan kerja yang dituntut oleh pekerjaan tersebut. Dengan demikian kompetensi menunjukkan keterampilan atau pengetahuan yang dicirikan oleh profesionalisme dalam suatu bidang tertentu sebagai suatu yang terpenting. Kompetensi sebagai karakteristik seseorang berhubungan dengan kinerja yang efektif dalam suatu pekerjaan atau situasi.

Menurut Spencer and Spencer dalam Prihadi (2004:38-39) terdapat 5 (lima) karakteristik kompetensi, yaitu :1. Motif (motive) adalah hal-hal yang seseorang pikir atau inginkan secara konsisten yang menimbulkan tindakan.2. Sifat (traits) adalah karakteristik fisik dan respons-respons konsisten terhadap situasi atau informasi..3. Konsep diri (Self - Concept) adalah sikap dan nilai-nilai yang dimiliki seseorang.4. Pengetahuan (Knowledge), adalah informasi yang dimiliki seseorang untuk bidang tertentu. Pengetahuan (knowledge) merupakan kompetensi yang kompleks.5. 
Ketrampilan (Skill). adalah kemampuan untuk melaksanakan suatu tugas tertentu baik secara fisik maupun mental.

Peneliti menyimpulkan bahwa kompetensi adalah kemampuan seseorang untuk bekerja dengan baik sesuai dengan tugas dan pokoknya dan didasarkan pada job descriptionya sehingga hasil pekerjaannya dapat dievaluasi dengan baik.

\section{Kompetensi Pedagogik}

Menurut Undang-Undang Republik Indonesia Nomor 14 Tahun 2005 tentang Guru dan Dosen Pasal 1 ayat (10) disebutkan "kompetensi adalah seperangkat pengetahuan, keterampilan,dan perilaku yang harus dimiliki, dihayati, dan dikuasai oleh guru atau dosen dalam melaksanakan tugas keprofesionalannya".

Menurut Sagala, (2009: 23). Rumusan kompetensi diatas mengandung tiga aspek, yaitu: (1) kemampuan, pengetahuan, kecakapan, sikap, sifat, pemahaman, apresiasi dan harapan yang menjadi ciri dan karakteristik seseorang dalam menjalankan tugas. Aspek ini menunjuk pada kompetensi sebagai gambaran substansi/materi ideal yang seharusnya dikuasai atau dipersyaratkan untuk dikuasai oleh guru dalam menjalankan pekerjaannya. (2) ciri dan karakteristik kompetensi yang digambarkan dalam aspek pertama itu tampil nyata (manifest) dalam tindakan, tingkah laku dan unjuk kerjanya. Aspek ini merujuk pada kompetensi sebagai gambaran unjuk kerja nyata yang tampak dalam kualitas pola pikir, sikap dan tindakan sesorang dalam menjalankan pekerjaannya secara piawai. (3) hasil unjuk kerjanya itu memenuhi suatu kriteria standar kualitas tertentu. Aspek ini merujuk pada kompetensi sebagai hasil (output dan atau outcome) dari unjuk kerja.

Kompetensi pedagogik merupakan suatu performansi (kemampuan) seseorang dalam bidang ilmu pendidikan. Untuk menjadi guru yang profesional haruslah memiliki kompetensi padagogik. Dalam Standar Nasional Pendidikan, penjelasan Pasal 28 ayat (3) butir a mengemukakan bahwa kompetensi pedagogik adalah kemampuan mengelola pembelajaran peserta didik yang meliputi pemahaman terhadap peserta didik, perancangan dan pelaksanaan pembelajaran, evaluasi hasil belajar, dan pengembangan peserta didik untuk mengaktualisasikan berbagai potensi yang dimilikinya.

Susilo (2011: 115), menjelaskan bahwa Kompetensi pedagogik adalah kemampuan guru dalam mengelola pembelajaran peserta didik, meliputi: menyiapkan perangkat pembelajaran, melaksanakan pembelajaran, dan evaluasi pembelajaran. 
Kemampuan paedagogik menurut Suparno (2002:52) disebut juga kemampuan dalam pembelajaran atau pendidikan yang memuat pemahaman akan sifat, ciri anak didik dan perkembangannya, mengerti beberapa konsep pendidikan yang berguna untuk membantu siswa, menguasai beberapa metodologi mengajar yang sesuai dengan bahan dan perkambangan siswa, serta menguasai sistem evaluasi yang tepat dan baik yang pada gilirannya semakin meningkatkan kemampuan siswa.

Peneliti menyimpulkan bahwa kompetensi pedagogik adalah kemampuan guru untuk mengelola pembelajaran, menguasai metode pembelajaran, dan mampu memotivasi siswa untuk belajar dengan baik, serta mampu mengevaluasi hasil belajar siswa.

\section{METODE}

Penelitian ini akan dilaksanakan kepada peserta didik di SMAN 21 Bekasi. Metode penelitian yang digunakan adalah kuantitatif metode survei dengan pendekatan model regresi ganda. Pengaruh antara variabel bebas dan variable terikat. Populasi dalam penelitian ini adalah seluruh peserta didik kelas X di SMAN 21 Bekasi yang berjumlah 98 siswa. Sedangkan untuk sampel diambil sebanyak 30 sampel yang didasarkan pada teori M.Iqbal Hasan (2002:58) mengatakan bahwa : "Sampel adalah bagian dari populasi yang diambil melalui cara-cara tertentu, juga memiliki karakteristik tertentu, jelas, dan lengkap yang bisa dianggap mewakili populasi. Menurut Arikunto, (2002:109), "Sampel adalah sebagian atau wakil populasi yang diteliti". Untuk ukuran banyaknya sampel dari suatu populasi ada beberapa ahli yang berpendapat. Menurut Gay, (dalam M.Iqbal Hasan ,2002:60), ukuran minimum sampel yang dapat diterima berdasarkan pada metode penelitian yang digunakan, yaitu sebagai berikut : metode deskriptif, minimal $10 \%$ populasi, untuk populasi relaif kecil minimal 20\%, metode deskriptif korelasional minimal 30 subyek, metode expost facto minimal 15 subjek perkelompok, dan metode eksperimental minimal 15 subyek perkelompok".

Peneliti menggunakan random sampling untuk mengambil sampel dari populasi. Penelitian ini dapat digambarkan seperti pada gambar 1. 


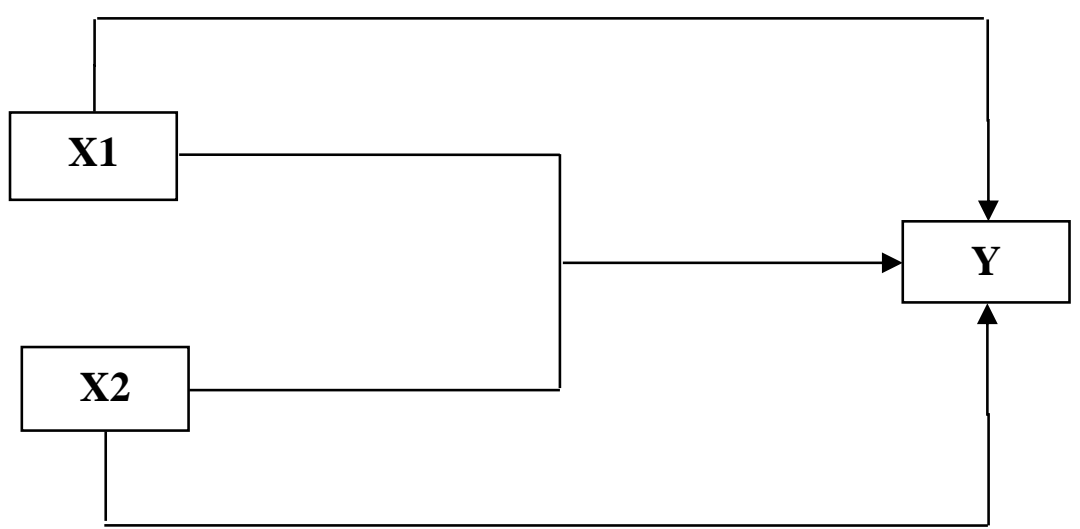

Gambar 1. Model Regresi Ganda

Keterangan:

$\begin{array}{ll}\mathrm{X} 1 & \text { : Persepsi Siswa Atas Fasilitas } \\ \mathrm{X} 2 & \text { : Persepsi Siswa Atas Kompetensi Pedagogik } \\ \mathrm{Y} & \text { : Hasil Belajar Ekonomi }\end{array}$

\section{HASIL DAN PEMBAHASAN}

Peneliti melakukan perhitungan dengan menggunakan bantuan program SPSS 22 menghasilkan deskripsi data yang dapat dilihat pada tabel berikut:

Tabel 1. Deskripsi Data Penelitian Statistics

\begin{tabular}{|c|c|c|c|c|}
\hline & & $\mathrm{X} 1$ & $\mathrm{X} 2$ & $\mathrm{Y}$ \\
\hline \multirow[t]{2}{*}{$\mathrm{N}$} & Valid & 30 & 30 & 30 \\
\hline & Missing & 0 & 0 & 0 \\
\hline \multicolumn{2}{|c|}{ Mean } & 34.37 & 43.03 & 78.47 \\
\hline \multicolumn{2}{|c|}{ Median } & 33.50 & 43.00 & 79.00 \\
\hline \multicolumn{2}{|c|}{ Mode } & $28^{\mathrm{a}}$ & $39^{\mathrm{a}}$ & 79 \\
\hline \multicolumn{2}{|c|}{ Std. Deviation } & 5.738 & 3.253 & 2.460 \\
\hline \multicolumn{2}{|c|}{ Variance } & 32.930 & 10.585 & 6.051 \\
\hline \multicolumn{2}{|c|}{ Range } & 24 & 11 & 9 \\
\hline \multicolumn{2}{|c|}{ Minimum } & 25 & 38 & 75 \\
\hline \multicolumn{2}{|c|}{ Maximum } & 49 & 49 & 84 \\
\hline
\end{tabular}




\section{Analisis Data}

\section{Hasil Belajar Ekonomi}

Data Hasil Belajar Ekonomi siswa mempunyai rata-rata 78,47, median 79,00 , modus 79, standar deviasi 2,460, varians 6,051, rentang 9, nilai terendah 75 ,dan nilai tertinggi 84 .

\section{Persepsi Siswa Atas Fasilitas}

Data Persepsi Siswa Atas Fasilitas mempunyai rata-rata 34,37, ,median 33,50, modus 28, standar deviasi 5,738, varians 32,930, rentang 24, nilai terendah 25, dan nilai tertinggi 49.

\section{Persepsi Siswa Atas Kompetensi Pedagogik Guru}

Data Persepsi Siswa Atas Kompetensi Pedagogik Guru mempunyai rata-rata 43,03, median 43,00, modus 39 , standar deviasi 3,253, varians 10,585, rentang 11 , nilai terendah 38 , dan nilai tertinggi 49.

\section{Pengujian Hipotesis}

Tabel 2. Hasil Perhitungan Koefisien Korelasi Pengaruh Variabel X1, dan X2, terhadap Y

\begin{tabular}{|l|r|r|r|r|}
\hline \multicolumn{1}{|c|}{} & & Model Summary \\
Model & $\mathrm{R}$ & R Square & \multicolumn{1}{c|}{$\begin{array}{c}\text { Adjusted R } \\
\text { Square }\end{array}$} & $\begin{array}{c}\text { Std. Error of the } \\
\text { Estimate }\end{array}$ \\
\hline 1 & $.406^{\mathrm{a}}$ & .165 & .103 & 2.330 \\
\hline
\end{tabular}

a. Predictors: (Constant), X2, X1

Tabel 3. Rekapitulasi Hasil Perhitungan Pengujian Signifikasi Koefisien Regresi Pengaruh Variabel X1,dan X2 terhadap Varibel Y

ANOVA $^{b}$

\begin{tabular}{|ll|r|r|r|r|r|}
\hline Model & & Sum of Squares & df & Mean Square & F & Sig. \\
\hline 1 & Regression & 28.905 & 2 & 14.453 & 2.663 & $.088^{\mathrm{a}}$ \\
& Residual & 146.561 & 27 & 5.428 & & \\
& Total & 175.467 & 29 & & & \\
\hline
\end{tabular}

a. Predictors: (Constant), X2, X1

b. Dependent Variable: Y 
Tabel 4. Rekapitulasi Hasil Perhitungan Persamaan Garis Regresi Pengaruh Variabel X1,dan X2 terhadap Varibel Y

\begin{tabular}{|c|c|c|c|c|c|c|}
\hline \multicolumn{7}{|c|}{ Coefficients $^{\mathrm{a}}$} \\
\hline \multirow{2}{*}{\multicolumn{2}{|c|}{ Model }} & \multicolumn{2}{|c|}{ Unstandardized Coefficients } & \multirow{2}{*}{$\begin{array}{c}\begin{array}{c}\text { Standardized } \\
\text { Coefficients }\end{array} \\
\text { Beta }\end{array}$} & \multirow[b]{2}{*}{$\mathrm{T}$} & \multirow[b]{2}{*}{ Sig. } \\
\hline & & B & Std. Error & & & \\
\hline 1 & (Constant) & 91.853 & 6.106 & & 15.044 & .000 \\
\hline & $\mathrm{X} 1$ & -.107 & .076 & -.250 & -1.413 & .169 \\
\hline & $\mathrm{X} 2$ & -.226 & .134 & -.298 & -1.690 & .103 \\
\hline
\end{tabular}

a. Dependent Variable: Y

a. Pengaruh Secara Bersama-sama Persepsi Siswa Atas Fasilitas terhadap dan Persepsi Siswa Atas Kompetensi Pedagogik Guru terhadap Hasil Belajar Ekonomi

Dari tabel 2. menunjukan bahwa hubungan antara Persepsi Siswa Atas Fasilitas dan Kompetensi Pedagogik Guru dengan Hasil Belajar Ekonomi adalah sedang yang ditunjukan dengan nilai 0,406. Sedangkan koefisien determinasinya sebesar 16,5\%. Ini artinya variabel Persepsi Siswa Atas Fasilitas dan Persepsi Siswa Atas Kompetensi Pedagogik Guru menjelaskan variabel Hasil Belajar Ekonomi sebesar 16,5 \% dan selebihnya yaitu sebesar 83,5 \% oleh faktor lain. Sedangkan untuk pengujian analisis regresi diperoleh hasil perhitungan yang terlihat pada tabel 4. diperoleh persamaan garis regresi yang mempresentasikan pengaruh variabel $\mathrm{X}_{1}$ dan $\mathrm{X}_{2}$ terhadap variabel $\hat{\mathrm{Y}}$,yaitu = $91,853-0,107 \mathrm{X}_{1}-0,226 \mathrm{X}_{2}$.

Pada tabel 3. Nilai Sig $0,088>0,05$ dan $\mathrm{F}_{\text {hitung }}=2,663$ artinya tidak terdapat pengaruh yang signifikan secara bersama-sama persepsi siswa atas fasilitas dan kompetensi pedagogik guru terhadap hasil belajar Ekonomi pada siswa SMAN 21 Bekasi Tahun Pelajaran 2017/2018.

\section{Pengaruh Persepsi Siswa Atas Fasilitas Terhadap Hasil Belajar Ekonomi}

Dari tabel 4. nilai $\operatorname{Sig}=0,169>0,05$ dan $t_{\text {hitung }}=-1,413$ artinya tidak terdapat pengaruh yang signifikan persepsi siswa atas fasilitas terhadap hasil belajar Ekonomi pada siswa SMAN 21 Bekasi Tahun Pelajaran 2017/2018. 


\section{Pengaruh Persepsi Siswa Atas Kompetensi Pedagogik Guru Terhadap Hasil Belajar Ekonomi}

Dari tabel 4. nilai Sig $=0,103>0,05$ dan $t_{\text {hitung }}=-1,690$ artinya tidak terdapat pengaruh yang signifikan kompetensi pedagogik guru terhadap hasil belajar Ekonomi pada siswa SMAN 21 Bekasi Tahun Pelajaran 2017/2018.

\section{SIMPULAN}

Berdasarkan hasil dan pembahasan yang telah di sajikan, maka dapat di simpulkan bahwa 1). Tidak terdapat pengaruh yang signifikan secara bersama-sama persepsi siswa atas fasilitas dan kompetensi pedagogik guru terhadap hasil belajar Ekonomi pada siswa SMAN 21 Bekasi Tahun Pelajaran 2017/2018, 2). Tidak terdapat pengaruh yang signifikan persepsi siswa atas fasilitas terhadap hasil belajar Ekonomi pada siswa SMAN 21 Bekasi Tahun Pelajaran 2017/2018, 3). Tidak terdapat pengaruh yang signifikan kompetensi pedagogik guru terhadap hasil belajar Ekonomi pada siswa SMAN 21 Bekasi Tahun Pelajaran 2017/2018.

\section{DAFTAR PUSTAKA}

A.Suhaenah Suparno. 2002. Membangun Kompetensi Belajar. Direktorat Jendral Pendidikan Tinggi Departemen Pendidikan Nasional.

Arikunto, Suharsimi dan Lia Yuliana. 2008. Manajemen Pendidikan. Yogyakarta: Aditya Media Yogyakarta.

Arikunto, Suharsimi. 2002. Prosedur Penelitian Suatu Pendekatan dan Praktek. Jakarta: Rineka Cipta.

B. Suryosubroto 2004. Manejemen Pendidikan di Sekolah. Jakarta: Rineka Cipta

Bimo, Walgito, 2004. Pengantar Psikologi Umum. Jakarta : Andi

Budimansyah, Dasim. 2003. Model Pembelajaran Ekonomi. Bandung: Genesindo.

Departemen Pendidikan Indonesia (2008). Kamus Besar Bahasa Indonesia. Jakarta: Balai Pustaka.

Depdiknas. 2002. Ringkasan Kegiatan Belajar Mengajar. Jakarta: Depdiknas

Dimyati, Mudjiono. 2006. Belajar dan Pembelajaran. Jakarta: Rineka Cipta. 
E. Mulyasa. 2004. Kurikulum Berbasis Kompetensi. Bandung: Remaja Rosdakarya Offset.

Edi Suparno. 2005. Pengaruh Kompetensi, Motivasi Kerja dan Kecerdasan Emosional Guru terhadap Kinerja Guru di SMP Negeri se-rayon barat Kabupaten Sragen.

Hasan, M Iqbal. 2002. Pokok-pokok Materi Statistika 1 (Statistik Deskriptif). Edisi. Kedua. Jakarta : Bumi Aksara

Kurniawan, Albert. 2014. Metode Riset Untuk Ekonomi \& Bisnis. Bandung : Alfabeta.

Nana Sudjana. 2009. Penilaian Hasil Proses Belajar Mengajar. Bandung: Remaja Rosdakarya.

Palan, R. 2007. Competency Management. Seri Manajemen SDM. Jakarta: PPM

Prihadi, S. 2004. Kinerja, Aspek Pengukuran. Jakarta: Gramedia Pustaka.

Sigit Winarno dan Sujana Ismaya. 2007. Kamus Besar Ekonomi. Bandung: Pustaka Grafika

Spencer, M. Lyle \& Spencer, M. Signe., 1993. Competence at Work., Canada: John Wiley \& Sons, Inc.

Sugihartono, dkk. 2007. Psikologi Pendidikan. Yogyakarta: UNY Press

Susilo. (2011). Perencanaan pembelajaran. Bandung: Remaja Rosda Karya

Syaiful Sagala. 2009. Konsep dan Makna Pembelajaran. Bandung : Alfabeta.

Wibowo, 2007. Manajemen Kinerja. Edisi Kedua. Jakarta : Raja Grafindo Persada. 